\title{
Búcsú a végrehajthatóvá nyilvánítási eljárástól
}

\author{
Brüsszel I. rendelet - külföldi határozat - elismerés - végrehajthatóvá nyilvánítás - \\ exequatur - végrehajtás
}

2015. január 10-én új időszámítás kezdődött az Európai Unió polgári eljárásjogában. Az igazságügyi együttműködés egyik legfontosabb jogforrását, a polgári és kereskedelmi ügyekben a joghatóságról, valamint a határozatok elismeréséröl és végrehajtásáról szóló 44/2001/EK rendeletet az 1215/2012/EU rendelet váltotta fel. Sok apróbb módosítás mellett a legfontosabb változtatás a végrehajthatóvá nyilvánítás vagy másképpen exequatur eljárás megszüntetése. A rendelet preambulumának 26. pontja szerint az igazságszolgáltatás müködése iránt az Unióban táplált kölcsönös bizalom már nemcsak a tagállamokban hozott határozatok automatikus elismerésének a feltételeit teremtette meg, hanem a végrehajtás előtti végrehajthatóvá nyilvánítás eltörlését is, ennek eredményeként egy tagállam bíróságai által hozott határozatot a végrehajtás szempontjából úgy kell tekinteni, mintha a címzett tagállamban hozták volna. A tanulmány, amely a rendelet hatálybalépésének az elöestéjén íródott, még elsősorban a múltra figyel: feltárja a végrehajthatóvá nyilvánítási eljárás jogi természetét és a nemzeti joggal való kapcsolatát, valamint bemutatja a közösségi szabályok hazai alkalmazásának tíz évét. Nem feltétlenül osztja a jogirodalom lelkesedését az új szabályozás iránt, de a jövőt illetően nem bocsátkozik találgatásokba.

\section{A végrehajthatóvá nyilvánítási (exequatur) eljárás jogi természetéről}

A végrehajthatóvá nyilvánítás a külföldi határozatok elismerése és végrehajtása közé ékelődő eljárás. A jogirodalom a végrehajtás „természetes előfeltételének” tekinti, amennyiben a végrehajtandó határozat egy másik ország bíróságától ered. ${ }^{1}$ Amikor a latin „exequatur” kifejezéssel illetjük, az eljárás engedélyező vagy beleegyező jellegére utalunk. Schack szerint az engedély megkövetelése a nemzeti szu-

* Dr. Kengyel Miklós egyetemi tanár, Pécsi Tudományegyetem, Állam- és Jogtudományi Kar; Andrássy Gyula Német Nyelvű Egyetem, Budapest, kengyel.miklos@ajk.pte.hu. A tanulmány alapjául szolgáló kutatás az Európai Unió és Magyarország támogatásával, az Európai Szociális Alap társfinanszírozásával a TÁMOP 4.2.4.A/1-11-1-2012-0001 azonosító számú „Nemzeti Kiválóság Program” című kiemelt projekt keretei között valósult meg.

1 Kramer, Xandra: Cross-Border Enforcement in the EU: Mutual Trust versus Fair Trial? Toward Principles of European Civil Procedure, International Journal of Procedural Law Vol. 1 (2011) Nr. 2, 215. 
verenitás megnyilvánulása és az államhatalom gyakorlása a végrehajtás területén. ${ }^{2}$ A belföldi végrehajtó csak egy belföldi bíróság utasításait követheti, külföldi bíróság parancsa nem köti. Mivel a végrehajtótól nem követelhető meg az, hogy a külföldi határozat végrehajthatóságát önállóan vizsgálja meg, ez a feladat a bíróságra hárul. $^{3}$ Oberhammer a végrehajthatóvá nyilvánítási eljárásban „jogcím importáló” és „jogcím ellenőrző” funkciót lát. Az előbbi alatt a külföldi határozat átvitelét érti abba az államba, amelyben a végrehajtást kérik. Az utóbbi annak a megállapítására irányul, hogy a külföldi határozat összeegyeztethető-e a végrehajtás helye szerinti állam jogrendjével. Az ellenőrzés lehetősége általában korlátozott és csak meghatározott okok vonatkozásában (közrend, véglegesség, összeegyeztethetöség) áll fenn. ${ }^{4}$ A végrehajthatóvá nyilvánítás megtagadásának alapjául szolgáló okok, amelyek úgy is megfogalmazhatók, mint az elismerés és a végrehajtás feltételei, országonként jelentősen különbözve egymástól, bonyolult rendszereket alkothatnak.

A külföldi bírósági határozatok elismerése és végrehajtása feltételeinek az egyszerüsítésére már a hatvanas években történtek kísérletek. Az International Law Association 1960-ban egy minta-egyezménytervezetet dolgozott ki, amelyet a Hágai Nemzetközi Magánjogi Konferenciához továbbítottak. ${ }^{5}$

Valódi áttörést az 1968. évi Brüsszeli Egyezmény ${ }^{6}$ hozott, amely alapvetöen átrendezte az ítéletet hozó állam és a végrehajtó állam bíróságának a viszonyát, amennyiben az előbbit megerősítette, az utóbbit pedig meggyengítette. Amint arra a Jenard-jelentés rámutatott, a végrehajtó állam bírájának gyakorlatilag csak két pontot kell vizsgálnia: a közrendet és az alperes jogainak a megóvását. A többi megtagadási okot a közrend határterületének minősítette. ${ }^{7}$

A végrehajthatóvá nyilvánításnak az 1968. évi Brüsszeli Egyezményben lefektetett szabályait jelentős tartalmi változtatásokkal ültették át a Brüsszel I. rendeletbe ${ }^{8}$ miközben a jogi természete változatlan maradt. Kropholler a végrehajthatóvá nyilvánítás önálló szabályozását az európai polgári eljárásjog jelentős részének nevezte. ${ }^{9}$

2 Schaск, Haimo: The misguided abolition of exequatur procedings in the European Union. In Gudowski, Jacek-Weitz, Karol (eds.): Aurea Praxis Aurea Theoria. Księga pamiątkowa ku czci Profesora Tadeusa Erecińskiego, Lexis Nexis, Warszawa, 2011, 1346.

3 SCHACK, Haimo: Internationales Zivilverfahrensrecht, C. H. Beck, München, 2002, 398.

4 Oberhammer, Paul: The Abolition of Exequatur, Praxis des internationalen Privat- und Verfahrensrecht, 30 (2010) 3, 197-199.

5 Report: $49^{\text {th }}$ conference, held at Hamburg, August $8^{\text {th }}$ to August $12^{\text {th }} 1960$. International Law Association, 1961. 290 és köv.

6 Egyezmény a bírósági joghatóságról és a határozatok végrehajtásáról a polgári és kereskedelmi ügyekben. Kelt Brüsszelben 1968. szeptember 27-én (HL L 299., 1972. 12. 31., 32-47.).

7 „....a végrehajtó állam bírájának a feladata korlátozottabb annál, amit a végrehajtásról szóló egyezmények általában elöírnak". JENARD, Paul: Bericht zu dem Übereinkommen über die Zuständigkeit und die Vollstrekkung gerichtlicher Entscheidungen in Zivil- und Handelssachen. Abl. EG 1979, C 59, 51.

8 A Tanács 44/2001/EK rendelete (2000. december 22.) a polgári és kereskedelmi ügyekben a joghatóságról, valamint a határozatok elismeréséről és végrehajtásáról (HL L 12., 2001. 01. 16., 1-38.).

9 KROPHOLLER, Jan: Europäisches Zivilprozessrecht, Kommentar zum EuGVÜ. Verlag Recht und Wirtschaft, Heidelberg, 1983. 287. Az első kiadásban tett megállapítását Kropholler később is fenntartotta. 
Az egyezmény, illetve a rendelet nemcsak a végrehajthatóvá nyilvánítás feltételeit szabályozta, hanem egy Európa-szerte egységes eljárást teremtett. ${ }^{10}$

A végrehajthatóvá nyilvánítási eljárás - az 1968. évi Brüsszeli Egyezményben, az 1988. évi és a 2007. évi Luganói Egyezményben, valamint a Brüsszel I. rendeletben található - félrevezető elnevezése ellenére nem azonos a tulajdonképpeni végrehajtási eljárással. Az előbbi túlnyomó részében az uniós jog által szabályozott egységes eljárás, míg az utóbbi továbbra is a nemzeti jog hatálya alatt áll. A végrehajthatóvá nyilvánítási vagy másképpen exequatur eljárást a jogirodalom ítélkezési eljárásnak tartja, de hangsúlyozza különös, ${ }^{11}$ egyszerű vagy - Mankowski megfogalmazása szerint - „erősen kurtított”12 jellegét. Különös ismérve a jogcímalkotó képessége. ${ }^{13} \mathrm{~A}$ végrehajthatóvá nyilvánítási eljárás során a származási államban hozott döntést végrehajtási jogcímmel ruházzák fel, ami a megkeresett államban a végrehajtás feltétele.

A végrehajthatóvá nyilvánítási eljárásban hozott döntés természetéről megoszlanak a vélemények. Az 1968. évi Brüsszeli és - vele egyezően - az 1988. évi Luganói Egyezmény ${ }^{14} 36$. és 39. cikke a végrehajtás engedélyezésének, míg a Brüsszel I. rendelet 41., 42., 43., 45., 47. és 53. cikke a végrehajthatóság megállapításának nevezi. ${ }^{15} \mathrm{~A}$ származási államban hozott határozat belföldi végrehajtási jogcímmel történő felruházása mindazonáltal több mint megállapítás. A common law jogrendszerek felfogása szerint a végrehajthatóvá nyilvánítás mintegy mulasztási ítéletként értelmezhető, hiszen a külföldi ítélet olyan kötelezettséget keletkeztet, amelyröl egy másik ország bíróságának kellett volna rendelkeznie. ${ }^{16}$ Geimer szerint jogalakító döntésröl van szó. ${ }^{17}$ Rauscher az eljárás tárgyára tekintettel nevezi a végrehajthatóvá nyilvánítást jogalakító döntésnek..$^{18}$ Ugyanezen a véleményen van Hess is, aki szerint a közösségi jogalkotó nem mondott le a végrehajthatóságnak mint joghatásnak a konstitutív megadásáról. ${ }^{19}$ Erre csak az „új vagy második generációsnak” nevezett rendeletek esetében került sor, amelyeknek a sorát a 85/2004/EK rendelet nyitotta meg.

10 Mankowski, Peter: Vollstreckung. In Rauscher, Thomas (Hrsg.): Europäisches Zivilprozess- und Kollisionsrecht. Kommentar, Brüssel I-VO, LugÜbk 2007, Sellier, München, 2011, 774.

11 Geimer, Reinhold-Schütze, Rolf: Europäisches Zivilverfahrensrecht, C. H. Beck, München, 2010, 715.

12 Mankowski, Peter: Coursier v. Fortis Bank - EuGH-Urteil vom 29. 4. 1999 (C-267/97) mit Anmerkung. Zeitschrift für Zivilprozeß International, 4. Band (1999), 276.

13 Geimer-Schütze: i. m., 714., Mankowski: Vollstreckung, i. m., 775.

14 Egyezmény a bírósági joghatóságról és a határozatok végrehajtásáról a polgári és kereskedelmi ügyekben. Kelt Luganóban 1988. szeptember 16-án (HL L 319., 1988. 11. 25., 9-21.)

15 A megállapítás még nagyobb hangsúlyt kap a francia normaszövegben, amely a „la décision est déclaré exécutoire”, illetve „une déclaration constatant la force exécutoire” kifejezéseket használja. Vö. GAUDEMETTALLon, Hélène: Compétence et exécution des jugements en Europe, L. G. D. J, Paris, 2010, 470-471.

16 Dicey, Albert-Morris, John-Coluins, Lawrence: Conflict of Law, Sweet and Maxwell, London, 2006, Rz. 14-006.

17 GeIMER-Schütze: i. m., 713.

18 „Ebben az eljárásban nem a származási államban megítélt követelés fennállásáról van szó, hanem arról, hogy a megkeresett államban fennállnak-e a végrehajthatóvá nyilvánítás feltételei, vagy másképpen megfogalmazva: a jogosult igényt tarthat-e a megkeresett államban a követelése végrehajthatóvá nyilvánítására”. MANKOWSKI: i. m., 776.

19 Hess, Burkhard: Europäisches Zivilprozessrecht, C. F. Müller, Heidelberg, 2010, 355. 
A végrehajthatóságról szóló első döntés egyoldalú eljárás keretében születik meg, amely csak a jogorvoslat során válik kontradiktóriussá. Az 1968. évi Brüsszeli Egyezmény 34. cikkével egyezően a Brüsszel I. rendelet 41. cikke is kimondta azt, hogy az a fél, aki ellen a végrehajtást kérték, az eljárásnak ebben a szakaszában a kérelemre észrevételt nem tehet. Az általános vélemény szerint az egyoldalúság egyfelől az eljárás gyorsaságát, másfelöl a „meglepetési effektust” szolgálja, amelyről már Jenard is megállapította, hogy „a végrehajthatóvá nyilvánítási eljárás sajátja kell hogy legyen, ha nem akarjuk az alperes számára azt a lehetöséget biztosíta$n i$, hogy a vagyonát a végrehajtás alól kivonja”. ${ }^{20} A z$ eljárás egyoldalúsága azért nem sérti a kétoldalú meghallgatás elvét, mert az ellenérdekü félnek lehetősége van arra, hogy a jogorvoslati kérelem benyújtásával a kontradiktórius eljárást kikényszerítse. ${ }^{21}$ Schlosser szerint a normaszöveg nem tiltja kategorikusan az ellenérdekü fél tájékoztatását, ezt azonban a nagyon kivételes esetekre kell korlátozni, mivel a végrehajtás hatékonysága szempontjából nélkülözhetetlen „meglepetési effektust” biztosítani kell. ${ }^{22}$

Kropholler szerint a rendeletben szabályozott végrehajthatóvá nyilvánítási eljárás a jogcímek megsokszorozódásához vezethet, mivel a hitelező az eljárást - elvileg - bármelyik tagállamban megindíthatja. A hitelező választhat, hogy melyik tagállamban akarja a határozatot végrehajtatni. ${ }^{23}$ Schlosser - a forum shopping mintájára ezt a lehetőséget „enforcement shopping”-nak nevezi, megjegyezve azt, hogy „nincs benne kivetnivaló", vagyis el kell fogadni azt, hogy a külföldi végrehajtásra bármelyik tagállam végrehajtási jogának a hatékonysága is motiválhat. ${ }^{24}$ Egyetlen józanul gondolkodó hitelező sem fog pénzt, időt és fáradságot fordítani a végrehajthatóvá nyilvánítási eljárásra egy olyan országban, ahol az adósnak nincs vagyona, vagy ahol még pernyertessége esetén sem juthat hozzá a követeléséhez.

\section{A végrehajthatóvá nyilvánítás a nemzeti jogban}

A végrehajthatóvá nyilvánítási eljárás szabályai az Európai Unió Bíróságának megállapítása szerint „önálló és zárt rendszert” képeznek. ${ }^{25} \mathrm{~A}$ Brüsszel I. rendelet 38-52. cikkei elsőbbséget élveznek a nemzeti joggal szemben, amelyeket csak a rendelet hézagainak a kitöltésére alkalmazhatnak. Ez a szabályozási módszer érvé-

20 JenARD: i. m., 50.

21 RASSI, Jürgen: Anerkennung und Vollstreckung. In Fasching, Hans-Konecny, Andreas (Hrsg.): Kommentar zu den Zivilprozeß-gesetzen, Manz, Wien, 2008, 5. Band/1. Teilband, 946; GeImeR-Schütze: i. m., 755; MANKOWSKI: Vollstreckung, i. m., 807; KROPHOLleR, Jan-VON HeIN, Jan: Europäisches Zivilprozessrecht. Verlag Recht und Wirtschaft, Frankfurt, 2011, 631.

22 Schlosser, Peter: Bericht zum 1. EuGVÜ-Beitrittsübereinkommen mit Dänemark, Irland und dem Vereinigten Königreich. Abl. EG 1979, C 59, 71-159, 219. pont.

23 Kropholler-Von Hein: i. m., 612.

24 Schlosser, Peter: EU-Zivilprozessrecht. Kommentar, C. H. Beck, München, 2003, 253.

25 Eric Coursier v Fortis Bank and Martine Coursier, née Bellami C-267/97. sz. ügyben 1999. április 29-én hozott ítélet (ECR 1999, I-02543) 25. pont. 
nyesült egyébként az európai joghatósági rendszer kialakítása során is. ${ }^{26}$ Mankowski a szabályozás rejtett és nyitott hézagairól beszél. ${ }^{27}$ Ez utóbbiak közé tartoznak azok az esetek, amikor a normaszöveg kifejezetten a nemzeti jog alkalmazására utal, mint például a Brüsszel I. rendelet 39., 40., 42., 43., 44., 47. cikkei esetében. Az öszszeillesztésre többféle módszer létezik. Németországban ${ }^{28}$ és Hollandiában ${ }^{29}$ külön törvényt hoztak, a legtöbb tagállamban azonban az általános szabályokat alkalmazzák a rendelet hézagainak a kitöltésére. A kontinentális gyakorlattól eltérő megoldás érvényesül az Egyesült Királyságban és Írországban, ahol az „action up on the foreign judgment"-et részesítik elönyben. ${ }^{30}$

Magyarországon a végrehajthatóvá nyilvánítási eljárás szabályainak az alkalmazása tízéves múltra tekint vissza. A kezdeti nehézségek áthidalását megkönnyítette az, hogy a végrehajtási jog harmonizálása már a kilencvenes évek közepén megkezdődött. ${ }^{31} A z$ 1994. évi végrehajtási törvénynek a külföldi határozatok végrehajtására vonatkozó XI. fejezete már a Brüsszeli Egyezmény rendelkezéseinek a figyelembevételével született meg. Az Nmjtvr. 2000. évi módosítására pedig az 1988. évi Luganói Egyezményhez való csatlakozás reményében került sor. ${ }^{32} \mathrm{~A}$ szabályozás során tudatosan megteremtett összhangra tekintettel Magyarországnak nem volt szüksége arra, hogy az Európai Unióhoz való csatlakozás előkészítése során külön törvényt hozzon a Brüsszel I. rendelet közvetlen alkalmazhatósága érdekében. Az ország már az európai uniós csatlakozásra történő felkészülés során megtette a rendeletekben elöírt közléseket; a 2345/2001. (XI. 22.) Korm. határozat kijelölte a végrehajthatóság megállapítása során eljáró bíróságokat, a határozataik elleni jogorvoslatot elbíráló bíróságokat, illetve meghatározta, hogy ez utóbbi bíróságok határozatai ellen milyen eljárás keretében lehet további jogorvoslattal élni. A közlések tartalma a csatlakozási szerződés értelmében ún. technikai adaptáció útján a rendelet részévé vált.

A Brüsszel I. rendelet alkalmazására tekintettel mindössze négy helyütt került sor a Vht. kiegészítésére, a végrehajthatóvá nyilvánítási tanúsítvány kiállításával (31/C §), a kézbesítési megbízottal (37/B §), a biztosítási intézkedésekkel (186-87. §), valamint a külföldi határozatok végrehajtásával kapcsolatban (210/A §). ${ }^{33} \mathrm{Ez}$ utóbbi rendelkezés egyértelművé tette azt, hogy a magyar bíróságok a rendelet hatálya alá tartozó határozatok végrehajthatóvá nyilvánítása során, amennyiben a rendelet

26 Kropholler-von Hein: i. m., 127.

27 MANKowsKI: Vollstreckung, i. m., 776.

28 Gesetz zur Ausführung zwischenstaatlicher Verträge und zur Durchführung von Verordnungen der Europäischen Gemeinschaft auf dem Gebiet der Anerkennung und Vollstreckung in Zivil- und Handelssachen vom 19. Februar 2001 (AVAG). BGBI. I. S 288.

29 Wet van 2 juli 2003 tot uitvoering van de verordening (EG) Nr. 44/2001 van de Raad van de Europese Unie van 22 december 2000 betreffende de rechterlijke bevoegdheid, de erkenning en de tenuitvoerlegging van beslissingen in burgerlijke en handelszaken (Uitvoeringswet EG-executieverordening).

30 GeIMER-SchütZe: i. m., 730.

31 KENGYEL Miklós: Die Neuregelung der Zwangsvollstreckung in Ungarn, Zeitschrift für Zivilprozeß International, 1. Band (1996) 211-234.

32 Kengyel Miklós: Magyarország a Luganói Egyezmény kapujában, Magyar Jog, 46. évf. (1999) 6. sz. 329-338.

33 A változtatásokat a 2004. július 15-én hatályba lépett 2004. évi LXV. törvény, a kézbesítési megbízottra vonatkozó szabályt a 2005. május 28-án hatályba lépett 2005. évi XXXVI. törvény tartalmazta. 
eltérő szabályokat nem tartalmaz, ugyanúgy járnak el, mint általában a külföldi határozatok végrehajtása során. ${ }^{34}$

Ha a határozat a rendelet 41 . cikke szerint végrehajtható, akkor a II. melléklet szerint eljáró, a törvényszék székhelyén működő járásbíróság (Budapesten a Budai Központi Kerületi Bíróság) a végzésével a külföldi határozatra végrehajtási tanúsítványt vezet, amelyben azt tanúsítja, hogy a határozat a magyar jog szerint a belföldi bíróság határozatával azonos módon végrehajtható.

A végzés jogerőre emelkedése után a bíróság a végrehajtási tanúsítvánnyal ellátott külföldi határozat alapján végrehajtási lapot állít ki (Vht. 209. §). Ezt a végrehajtást kérőnek nem kell külön kérnie, hiszen a végrehajtási kérelem előterjesztése már az eljárás kezdetén, a végrehajtási tanúsítvány kiállítása előtt megtörtént. A végrehajtási lap kiállítása egyben a végrehajtás elrendelését jelenti.

A jogorvoslati kérelmet az egyes tagállamokban a Brüsszel I. rendelet III. mellékletében megjelölt bíróságokhoz kell benyújtani. A felsorolás 2004-ben kiegészült az új tagállamokra vonatkozó adatokkal. Magyarországon a jogorvoslati kérelmeket a törvényszék bírálja el.

A Brüsszel I. rendelet IV. mellékletben felsorolt nemzeti jogorvoslatok közös sajátossága az, hogy a megtámadott határozatnak csak a korlátozott felülvizsgálatát teszik lehetővé. Magyarországon a törvényszék jogorvoslat tárgyában hozott határozatát felülvizsgálati kérelemmel lehet megtámadni (Pp. 270-275. §). A jogerős ítélet vagy az ügy érdemében hozott jogerös végzés felülvizsgálatát a felek jogszabálysértésre hivatkozással kérhetik a Kúriától (Pp. 270. §).

\section{A végrehajthatóvá nyilvánítási eljárás a magyar joggyakorlatban}

A magyar csatlakozás óta eltelt tíz év alatt többször is megvizsgálták a végrehajthatóvá nyilvánítási eljárások számát és időtartamát, valamint a rendelet szabályainak az átültetését a hazai joggyakorlatba. A magyar bíróságoktól első alkalommal 2005 tavaszán kértek adatokat a Brüsszel I. rendelet alkalmazására vonatkozóan. Az Országos Igazságszolgáltatási Tanács hivatalának összesítése szerint egy év alatt 39 végrehajthatóvá nyilvánítási kérelem érkezett a bíróságokhoz. A kérelmek többségét a főváros területére illetékes Budai Központi Kerületi Bírósághoz nyújtották be.

2006-ban e tanulmány szerzője nemzeti referensként vett részt abban az öszszehasonlító kutatásban, amely az Európai Bizottság megbízásából a Brüsszel I. rendelet alkalmazását vizsgálta. Az empirikus vizsgálat eredményei önállóan ${ }^{35}$ és a The Heidelberg Report ${ }^{36}$ részeként is megjelentek.

34 A 210/A § (1) bekezdése 2010-ben egy újabb ponttal egészült ki: „b) a hágai jegyzőkönyv hatálya alá nem tartozó tagállamban, a 4/2009/EK tanácsi rendelet szerinti tartási ügyben hozott bírósági határozat (perbeli egyezség) és kiállított közokirat végrehajthatóságának megállapítására irányuló eljárás során - ha a 4/2009/ EK tanácsi rendelet másképpen nem rendelkezik - [a bíróság] az e Fejezetben foglaltak szerint jár el".

35 KENGYel Miklós: A Tanács 44/2001/EK (Brüsszel I.) rendeletének alkalmazása a hazai joggyakorlatban. Egy empirikus vizsgálat tapasztalatai, Európai Jog, 7. évf. (2007) 2. sz. 37-45.

36 Hess, Burkhard-Pfeiffer, Thomas-Schlosser, Peter: The Brussels I-Regulation (EC) No 44/2001. The Heidelberg Report on the Application of Regulation Brussels I in 25 Member States (Study JLS/C4/2005/03), C. H. Beck, München, 2008. 
2006-ban a végrehajthatóvá nyilvánítási eljárások számának kisméretű növekedését tapasztaltuk. Itt jegyezzük meg, hogy „nagy áttörésre” vagy tömegméretü ügyérkezésre a későbbiekben sem került sor. ${ }^{37} A$ végrehajthatóvá nyilvánítás iránti kérelmek a leggyakrabban Németországból, Ausztriából és Olaszországból, ritkábban Szlovákiából és Lengyelországból érkeztek ${ }^{38}$ Túlnyomó többségük jogerős bírósági határozat végrehajthatóvá nyilvánítására irányult. Közokiratra vonatkozó kérelmet mindössze két esetben nyújtottak be.

A kérelem mellékleteiröl megállapítottuk azt, hogy a magyar bíróságok a rendelet megengedő szabályai ellenére (53., 55. cikk) is megkövetelték a tanúsítvány bemutatását, és a külföldi határozat teljes szövegének, tehát a rendelkező résznek és az indokolásnak a hiteles fordítását is. ${ }^{39} \mathrm{~A}$ jogi képviselök általában külön felszólitás nélkül csatolták a végrehajthatóvá nyilvánítás iránti kérelemhez a külföldi határozat hiteles fordítását. Ennek hiányában a bíróság hivatalból rendelte el a fordítást.

A Brüsszel I. rendelet 52. cikkére tekintettel az illetékekröl szóló 1990. évi XCIII. törvény 57 . $§(1)$ bek. $m$ ) pontja az Európai Unió külföldi tagállamaiban hozott bírósági ítélet végrehajtását kezdeményező eljárást illetékmentessé nyilvánította. Ezt a szabályt a bíróságok úgy értelmezték, hogy az illetékmentesség a végrehajtási tanúsítvány jogeröre emelkedése után kiállított végrehajtási lapra is kiterjed (Vht. 209. §). A törvény 2010. évi módosítása ${ }^{40}$ azonban egyértelművé tette, hogy az illetékmentesség csak a belföldi végrehajthatóság megállapítása iránti eljárásra vonatkozik. ${ }^{41}$

A magyar bíróságok előtti végrehajthatóvá nyilvánítási eljárásban az ügyvédi részvétel - a többi tagállamhoz hasonlóan - nem kötelező. ${ }^{42} A$ végrehajtást kérők elsősorban az eljárás határon átnyúló jellege miatt vették igénybe az ügyvéd segítségét. Az ügyvéd munkadíját azonban csak a 12/1994. (IX. 8.) IM rendeletben meghatározott mértékig lehetett az adóssal szemben felszámítani. ${ }^{43} \mathrm{Az}$ eljárásban költségként merült még fel a külföldi határozat (közokirat, perbeli egyezség) hiteles fordításának a díja is.

A perköltség viselésének általános elvei a végrehajtási eljárásban is érvényesültek. A Vht. 34. §-a szerint a végrehajtást kérő által elölegezett költségeket az adós viseli. A végrehajtás során befolyt összegböl a végrehajtó visszatéríti a végrehajtást kérő által előlegezett költségeket. Ezt az adós azzal tudja késleltetni, ha a végrehaj-

37 Hivatalos statisztika hiányában csak becslésre szorítkozhatunk: Magyarországon a határon átnyúló polgári ügyek száma - a kézbesítési, a bizonyításfelvételi és az európai fizetési meghagyás kibocsátására irányuló ügyek nélkül - jelenleg sem haladja meg az évi néhány százat.

38 2006-ban Magyarország hét szomszédja közül négy (Horvátország, Románia, Szerbia és Ukrajna) még nem volt tagja az Európai Uniónak. Ezekből az országokból, különösen Ukrajnából és Romániából sok végrehajthatóvá nyilvánítási kérelem érkezett, amelyeknek az elbírálása a kétoldalú jogsegélyegyezmények alapján történt.

39 Hess ellenkező példákat is említ: „In many Member States a translation is not required if the judgment is written in English and if it is brief and easy to understand". In Hess-PFEIFFER-Schlosser: i. m., 127.

40 Az Itv. 57. § (1) bek. u) pontját a 2010. évi CXXVII. törvény iktatta be.

41 A Brüsszel I. rendelet 52. cikkét a külföldi joggyakorlat is szüken értelmezi. Vö. KROPHOLLeR-VON HEIN: i. m., 672, MANKowski: Vollstreckung, i. m., 825.

42 Kivételt csak Belgium képez, ahol a Code de procédure civile 1025. cikke elöírja az ügyvédi részvételt. Vö. Hess-Pfeiffer-Schlosser: i. m., 127.

43 Az ügyvéd munkadija nem lehet több, mint a végrehajtási ügyérték 1\%-a, ami költségátalány címen legfeljebb $30 \%-k a l$ növelhető. 
tás befejezésekor a végrehajtó által összeállított díjjegyzék ellen kifogást nyújt be. A kifogás alapján a bíróság a díjjegyzéket végzéssel módosíthatja, és e határozata ellen a felek és a végrehajtó is fellebbezhetnek. ${ }^{44}$

$A z$ a végrehajtást kérő, aki a származási tagállamban teljes vagy részleges költségkedvezményben, illetve költség- vagy illetékmentességben részesült, Magyarországon - a Brüsszel I. rendelet 50. cikkének megfelelően - a Pp. 84. §-a szerinti költségmentességre jogosult. A költségkedvezmény ipso iure, azaz külön engedélyezési eljárás lefolytatása nélkül illette meg, de csatolnia kellett a rendelet 54 . cikkében elöírt V. sz. formanyomtatványt, amelynek 5. pontja igazolta azt, hogy a határozatot hozó államban részesült-e valamilyen perköltségkedvezményben. A kedvezményezett személyt nem kötelezhették a költségek elölegezésére és megfizetésére, továbbá pártfogó ügyvéd kirendelésére is igényt tarthatott. Az állam által elölegezett végrehajtási költségeket behajthatatlanság esetén az állam viselte.

A végrehajthatóvá nyilvánítási eljárás időtartamára nézve már a 2006. évi empirikus vizsgálat során is kedvezö tapasztalatokat szereztünk. A Budai Központi Kerületi Bíróságon, amely a fővárosban lakó adósok ellen indított eljárásokra volt illetékes, a kérelem benyújtása és a végrehajthatóvá nyilvánító határozat meghozatala között alig egy hét telt el. Hiánypótlás elrendelése esetén a határidő egy hónappal hoszszabbodott meg. Jogorvoslat hiányában a határozat egy hónapon belül jogeröre emelkedett. Olyan eset, amelyre nézve a Brüsszel I. rendelet 43. cikk (5) bekezdése két hónapos jogorvoslati határidőt írt elő, a vizsgált mintában nem fordult elő. A határozat jogerőre emelkedése után a bíróságnak végrehajtási lapot kellett kiállítania, ami átlagosan újabb egy hónapot vett igénybe. Összességében azt állapítottuk meg, hogy a Budai Központi Kerületi Bíróságon, ahol a legtöbb - a Brüsszel I. rendeleten alapuló - végrehajthatóvá nyilvánítási ügyet intézik, a kérelem benyújtása és a végrehajtás megkezdése között átlagosan három hónap telt el, amennyiben a végrehajthatóvá nyilvánítást kimondó határozat ellen nem nyújtottak be jogorvoslatot. ${ }^{45}$

A 2009. évi empirikus vizsgálat ${ }^{46}$ az eljárás újabb részleteit tárta fel. A négy dunántúli megyére ${ }^{47}$ kiterjedő adatgyüjtés során bebizonyosodott az, hogy az országhatár, különösen Ausztria közelsége, mindkét irányba $n^{48}$ "generálja” a határon átnyúló végrehajtási ügyeket. Nem változott lényegesen az ítéletet hozó államok sorrendje sem, de Ausztria, Németország, Szlovákia és Olaszország mellé Románia is felzárkózott, mint 2007 óta az Európai Unió tagállama. A több mint száz ügyböl álló minta összetétele rendkívül változatos volt, de $46 \%$-uk gyermektartásdijak behajtására irányult, mivel ezek az ügyek a vizsgálat idején még a Brüsszel I. rendelet hatálya alá tartoztak. 49

44 14/1999 (IX. 4.) IM rendelet 22. §.

45 Kengyel: A Tanács 44/2001/EK (Brüsszel I.) rendeletének alkalmazása... i. m., 41-42.

46 GÉCZINÉ BÁRDosı Eszter: A határokon átnyúló végrehajtási eljárások a magyar bírósági gyakorlatban - egy összehasonlító vizsgálat tanulságai, Európai Jog, 10. évf. (2010) 3. sz. 25-31.

47 Győr-Moson-Sopron, Komárom-Esztergom, Vas és Veszprém megye.

48 A vizsgálat nemcsak a külföldi határozatok végrehajthatóvá nyilvánítására, hanem a magyar bírósági határozatok tanúsítvánnyal történő ellátására (Brüsszel I. rendelet 54. cikk), sőt a 805/2004/EK rendelet alapján a közvetlen végrehajtásra is kiterjedt.

49 A tartási ügyek 2011. június 18-tól a 4/2009/EK rendelet hatálya alá tartoznak. 
A bíróságok továbbra is szigorúan ragaszkodtak a Brüsszel I. rendelet 53. cikkében leírt alaki feltételekhez, és gyakran rendeltek el hiánypótlást. A hiteles fordítás általában egy hónapon belül elkészült, de a tanúsítvány külföldröl történő beszerzése két-három hónappal is késleltette az eljárás befejezését. Összességében a 2009. évi vizsgálat eredménye nem tért el a 2006. évitöl: a végrehajtási kérelem benyújtása és a végrehajtás megkezdése között átlagosan három hónap telt el..$^{50}$

A végrehajthatóvá nyilvánítási eljárás nemcsak gyorsnak, hanem hatékonynak is bizonyult. A bíróságok az ügyek $88 \%$-ában nyilvánították végrehajthatónak a külföldi határozatot, ami alig tért el a 90\%-os európai átlagtól. ${ }^{51} \mathrm{~A}$ végrehajthatóságról szóló határozat ellen benyújtott fellebbezések aránya (8\%) pedig mindössze néhány százalékkal haladta meg az európai átlagot. ${ }^{52} \mathrm{~A}$ fellebbezésben leggyakrabban arra hivatkoztak, hogy az ítéletet hozó államban nem kézbesítették a keresetlevelet kellő időben ahhoz, hogy az alperes a védekezésre felkészülhessen..$^{53} \mathrm{~A}$ fellebbezések elbírálása átlagosan 2-3 hónapot vett igénybe, ami lényegesen jobb az Európai Unió átlagánál, mivel egyes tagállamokban 1-2 évig is eltarthat a jogorvoslat elbírálása. ${ }^{54}$ A 2009. évi vizsgálatról szóló beszámoló két figyelemre méltó megállapítással zárult. Az egyik szerint „Nyugatról Keletre a bírósági határozatok szabadabban áramlanak, mint Keletröl Nyugatra", ami azt igazolja, hogy az igazságszolgáltatás müködése iránt az Unióban táplált kölcsönös bizalom még nem teljes az új tagállamokkal szemben. A másik szerint pedig a határozatok, bírói egyezségek és közokiratok EK rendeletek által szabályozott szabad áramlása ténylegesen megvalósult, alapvetően jól müködik. ${ }^{55}$

A Brüsszel I. rendeletben szabályozott végrehajthatóvá nyilvánítási eljárás sajátossága az volt, hogy az adós csak a jogorvoslati eljárásban adhatta elő a védekezését. Az eljárásnak ebben a szakaszában hivatkozhatott a megtagadási okokra (34. cikk) vagy a joghatóság hiányára (35. cikk). A 2012. évi empirikus kutatás a jogorvoslati eljárás tartalmi kérdéseivel, különösen az eljárási közrend megsértésével foglalkozott. ${ }^{56} \mathrm{~A}$ vizsgálathoz mintegy harminc, a Budai Központi Kerületi Bíróság végrehajthatóságot megállapító határozata ellen benyújtott fellebbezés került kiválasztásra. Az ügyek túlnyomó többségében a másodfokú bíróság a fellebbezést alaptalannak találta, és elutasította. Két esetben az elsőfokú bíróság határozatát hatályon kívül helyezték, és új eljárásra utasítottak, míg egy esetben a másodfokú bíróság helyt adott a fellebbezésnek, és a végrehajthatóvá nyilvánítás iránti kérelmet elutasította. A jogorvoslat tárgyában hozott döntéssel szemben két esetben nyújtottak be felülvizsgálati kérelmet, mint további jogorvoslatot (44. cikk). Az ügyek egyharmadában a fellebbezés alapjául olyan okot jelöltek meg, amelyet a másodfokú bíróság egyáltalán nem vehetett figyelembe ( $\mathrm{pl}$. az adós nehéz anyagi helyzete), vagy amely a

50 GÉCZINÉ: i. m., 29.

51 Vö. Hess-Pfeiffer-Schlosser: i. m., 14.

52 Hess a fellebbezések átlagát 1-5\% között jelölte meg. Vö. Hess-PfEeIfFER-SCHLOSsER: i. m., 127.

53 GÉCZINÉ: i. m., 30.

54 Hess-Pfeiffer-Schlosser: i. m., 150.

55 GÉCZINÉ: i. m., 30-31.

56 KaLıCzka Alexandra: $A$ védekezéshez való jog érvényesithetősége az Európai Unióban. Az adós eljárási alapjogainak védelme határon átnyúló végrehajtás során, PhD-értekezés, Budapest, 2013, 83-105. 
végrehajthatóvá nyilvánítás szempontjából nem volt releváns (pl. az adós már megkezdte a tartozás rendezését). Néhány fellebbezés az érdemi felülvizsgálat (révision au fond) tilalmába (36. cikk) ütközött. Hét esetben az (eljárási) közrend sérelmét [34. cikk (1) pont] jelölték meg a fellebbezés alapjául, amelyet eljárási hibákkal vagy az anyanyelvhasználat jogának a megsértésével támasztottak alá. A fellebbezések közül egy vezetett sikerre: a Budai Központi Kerületi Bíróság a megismételt eljárásban megállapította azt, hogy az osztrák bíróság megsértette a magyar alperesnek az anyanyelv használatához való jogát, amikor német nyelven levelezett vele. A bíróság végzését a másodfokon eljáró Fővárosi Bíróság helybenhagyta, a Legfelsőbb Bíróság pedig hatályában fenntartotta. ${ }^{57} \mathrm{Az}$ anyagi közrend megsértésére nem történt hivatkozás. ${ }^{58} \mathrm{~A}$ fellebbezések további egyharmadában a 34. cikk (2) pontja alá sorolható eljárási hibákra hivatkoztak (kézbesítés hiányosságai, iratok nyelve stb.). A védekezés túlnyomó részben sikertelen volt, bár meg kell jegyezni, hogy egyes esetekben a másodfokú bíróság az érdemi felülvizsgálat tilalmára hivatkozással zárkózott el az eljárási hibák vizsgálatától. Mindössze egyetlen esetben állapította meg a fellebbviteli bíróság azt, hogy az iratok fordításának hiánya miatt sérültek az adósnak a védekezéshez való jogai. ${ }^{59}$ Több fellebbezést nyújtottak be arra hivatkozással, hogy a végrehajthatóvá nyilvánított határozatot az adós távollétében hozták. Mivel ezek a származási állam jogának megfelelő mulasztási ítéletek voltak, a fellebbező fél kifogásait a másodfokú bíróság nem vette figyelembe. ${ }^{60}$

\section{Végrehajtás exequatur eljárás nélkül}

A végrehajthatóvá nyilvánítási eljárás megszüntetésének a gondolata csaknem egyidős a Brüsszel I. rendelet keletkezésével. Jóllehet az 1999. évi tamperei program ${ }^{61}$ csak általában akarta javítani a határozatok kölcsönös elismerésének a feltételeit, mégis kezdetét vette az a fejlődés, amely Rechberger szerint „napjainkra különös szakítóeröre tett szert". ${ }^{62}$

57 A bíróság arra a következtetésre jutott, hogy az adósnak nem volt lehetősége arra, hogy az iratok tartalmát pontosan megismerje, s annak megfelelően gyakorolja perbeli jogait. Ennélfogva „a külföldi határozat elismerése nemcsak az anyanyelv használatának magyar polgári eljárásjogi alapelvét, hanem a perbeli esélyegyenlőség megvalósítását biztosító, a Pp. 7. § (2) bekezdésében megfogalmazott tájékoztatási kötelezettség alapelvét is súlyosan sértené". (Vh. 0102.4266/2005, Vh. 1854/2006 és 4/A Vh. 5451/2006 sz. ügy).

58 KaLICZKA: $A$ védekezéshez való jog... i. m., 84.

$59 \mathrm{Az}$ adós álláspontja szerint a romániai bíróság megsértette a védekezéshez füződő jogát, mivel minden iratot román nyelven kézbesített neki, melyet egyébként nem beszél. A Fővárosi Törvényszék az első fokú bíróság végzését megváltoztatta, és elutasította a végrehajthatóság megállapítása iránti kérelmet (Vh. 0102.5244/2010 sz. ügy).

60 KaLiczKa: $A$ védekezéshez való jog.... i. m., 89.

61 http://www.europarl.europa.eu/summits/tam_de.htm (2014. 06. 21.).

62 ReChBERger, Walter H.: Grenzenloses Vertrauen in die Rechtssprechung der anderen Mitgliedstaaten? Überlegungen aus Anlass der geplanten Abschaffung des Exequaturverfahren in der EuGVVO. In Gudowski, Jacek-Weitz, Karol (eds.): Aurea Praxis Aurea Theoria. Księga pamiątkowa ku czci Profesora Tadeusa Erecińskiego, Lexis Nexis, Warszawa, 2011, 1278. 
Az Európai Unió Tanácsa kezdetben csak a bagatell eljárásoknál vagy a tartási és láthatási ügyeknél tervezte a határozatok elismerése és végrehajtása közé ékelődött eljárás leépítését. A köztes eljárás megszüntetését egyidejüleg az eljárási minimumszabályok lerögzítésétől kívánta függővé tenni. Konkrétabb célkitüzéseket tartalmazott a 2000. november 30-án elfogadott intézkedési program ${ }^{63}$, amely a nem vitatott követelésekre, valamint - Franciaország kezdeményezésére - a Brüsszel II. rendelet hatálya alá tartozó láthatási jogokra nézve is az exequatur eljárás eltörlését javasolta. Ez utóbbi a Tanács 2201/2203/EK rendeletével valósult meg, ${ }^{64}$ amely nemcsak a láthatási jogokra, hanem a gyermek visszaviteléről szóló határozatokra is kimondta, hogy „az összes tagállamban el kell ismerni és végre kell hajtani anélkül, hogy további eljárásra lenne szükség" (41-42. cikk).

Miután a 2000. évi intézkedési program az exequatur eljárás eltörlését a nem vitatott követelések esetében is a közösség prioritásai közé emelte, 2001 első félévében, a svéd elnökség alatt már kirajzolódtak a rendelet körvonalai. ${ }^{65} \mathrm{~A}$ Bizottság 2002 áprilisában hozta nyilvánosságra a nem vitatott követelések végrehajtásáról szóló tervezetet, ${ }^{66}$ amelyet a Gazdasági és Szociális Bizottság, valamint az Európai Parlament állásfoglalására tekintettel 2003-ban átdolgozott. ${ }^{67} \mathrm{Az}$ Európai Parlament és a Tanács 2004. április 21-én fogadta el a 805/2004/EK rendeletet a nem vitatott követelésekre vonatkozó európai végrehajtható okirat létrehozásáról. ${ }^{68}$

A jogirodalomban paradigmaváltásként értékelt új rendelet megnyitotta az utat az exequatur eljárás nélküli végrehajtás előtt. ${ }^{69} \mathrm{~A}$ végrehajthatóvá nyilvánítás helyébe - a származási tagállam feladataként - a végrehajtandó határozat európai végrehajtási jogcímmel való felruházása lépett. A jogirodalom nem fukarkodott a dicsérettel. Kropholler a rendelet gazdasági jelentőségét hangsúlyozta, tekintettel arra, hogy a határon átnyúló végrehajtási ügyek mintegy $90 \%$-a a nem vitatott követelések közé tartozik. ${ }^{70}$ Hess szerint a rendelet alkalmazása tartósan megkönnyíti a jogelismerésen és mulasztáson alapuló ítéletek határon átnyúló érvényesítését. ${ }^{71}$ Pabst némi fenntartással elismerte azt, hogy az exequatur eltörlése révén az azzal együtt járó késedelem és költség elkerülhető. ${ }^{72}$ Rechberger - bár néhány szerző dicséretét túláradónak tartotta - mégis úgy vélte, hogy ezzel a rendelettel a jövőben az Európai

63 Maßnahmenprogramm zur Umsetzung des Grundsatzes der gegenseitigen Anerkennung gerichtlicher Entscheidungen in Zivil- und Handelssachen. Abl 2001 C 12, 1-12.

64 A házassági ügyekben és a szülői felelősségre vonatkozó eljárásokban a joghatóságról, valamint a határozatok elismeréséről és végrehajtásáról, illetve az 1347/2000/EK rendelet hatályon kívül helyezéséről szóló 2201/2003/EK rendelet (HL L 338. 2003.12. 03., 1-29.).

65 Kropholler-von Hein: i. m., 771-772.

$66 \operatorname{COM}(2002) 159$ final.

$67 \mathrm{COM}(2003) 341$ final.

68 HL L 143, 2004. 04. 30., 15-39.

69 Rechberger, Walter: EuVTVO. In Fasching, Hans-Konecny, Andreas (Hrsg.): Kommentar zu den Zivilprozeßgesetzen, Manz, Wien, 2008, 5. Band/1. Teilband, 1288.

70 KROPHOLLER, Jan: Europäisches Zivilprozessrecht, Verlag Recht und Wirtschaft, Frankfurt, 2005, 568.

71 HeSS: i. m., 538.

72 PABST, Steffen: EG-Vollstr-TitelVO. In Rauscher, Thomas (Hrsg.): Europäisches Zivilprozess- und Kollisionsrecht. Kommentar, Sellier, München, 2010, 22. 
Igazságügyi Térben „szabadon áramló” határozatok, illetöleg végrehajtható okiratok „álma” valósággá válhat. ${ }^{73}$

A lelkes fogadtatásba egyetlen „disszonáns hang” vegyült: a közrendi záradék kiiktatása miatti aggodalom. ${ }^{74} \mathrm{~A}$ német szerzők többsége - a Krombach/Bamberski ügy ${ }^{75}$ ellenére - mégis arra az álláspontra helyezkedett, hogy az Emberi Jogok Európai Egyezményének 6. cikkében lefektetett biztosítékok az ítélkezési eljárás során kielégítően érvényesülnek, ezért nincs szükség a védelem megduplázására a végrehajtó állam bíróságai részéről. ${ }^{76}$ Pabst szerint a 805/2004/EK rendelet sikere végső soron attól függ, hogy a tagállamok mennyiben állnak készen arra, hogy a nemzeti eljárásukat a rendelet minimumszabályaihoz (12-19. cikk) igazítsák. ${ }^{77}$ Kropholler nem zárta ki, hogy egyes esetekben az (ebbe) „beleütköző megoldásokat is el kell fogadni" ${ }^{78}$ Másfelöl a közrendi záradék hiánya a jogbiztonságot szolgálja, mivel az adóst megfosztja az időhúzása lehetőségétől, és megteremti valamennyi tagállamban a gyors végrehajtás lehetőségét.

Az exequatur eljárás eltörlésével a 805/2004/EK rendelet a 2000. évi intézkedési programban neki szánt kísérleti projekt szerepét is betöltötte. Ezt a megoldást követte néhány évvel később az 1896/2006/EK rendelet a fizetési meghagyásról, a 861/2007/EK rendelet a kis értékü követelések európai eljárásáról, a 4/2009/EK rendelet a tartási ügyekröl a 2007. évi hágai jegyzőkönyv hatálya alá tartozó tagállamokban meghozott határozatok tekintetében, valamint a 2015. január 10-én hatályba lépő, megújított Brüsszel I. rendelet is. ${ }^{79}$ Miután a 805/2004/EK rendelet 2005. január 21-én lépett hatályba, az előző évben csatlakozott Magyarország kezdettől fogva alkalmazhatta, de a nemzeti jogot hozzá kellett igazítania a rendelet elöírásaihoz. ${ }^{80} \mathrm{Az}$ exequatur nélküli végrehajtás során a bíróság feladata arra korlátozódik, hogy az európai végrehajtó határozatként hitelesített külföldi határozat vagy bírósági egyezség alapján végrehajtási lapot, közokirat esetében pedig végrehajtási záradékot állítson $\mathrm{ki}$, ami a végrehajtás elrendelését jelenti. Az európai végrehajtható

73 ReCHBERGeR, Walter: Das europäische Zivilprozessrecht am Vorabend der großen Erweiterung der Europäischen Union. In Kiss Daisy-Varga István (szerk.): Magister artis boni et aequi. Studia in honorem Németh János, ELTE, Budapest, 2003, 729.

74 A 805/2004/EK rendelet 5. cikke szerint a származási államban európai végrehajtható okiratként hitelesített határozatot a többi tagállamban a végrehajthatóvá nyilvánítás szükségessége és az elismerés megtámadhatóságának lehetősége nélkül el kell ismerni és végre kell hajtani.

75 Dieter Krombach kontra André Bamberski C-7/98. sz. ügyben 2000. március 28-án hozott ítélet (ECR 2000, I-01935).

76 WAGNER, Rolf: Vom Brüsseler Übereinkommen über Brüssel I-Verordnung zum Europäischen Vollstreckungstitel. Praxis des internationalen Privat- und Verfahrensrecht, Vol. 22 (2002) Nr. 2, 87; StEIN, Andreas: Der Europäischer Vollstreckungstitel für unbestrittene Forderungen tritt in Kraft - Aufruf zu einer nüchterner Betrachtung. Praxis des internationalen Privat- und Verfahrensrecht, Vol. 24 (2004) 186; KROPHOLleR: Europäisches Zivilprozessrecht... (2005) i. m., 582. és köv.

77 PABST: i. m., 23.

78 KROPHOLleR: Europäisches Zivilprozessrecht... (2005) i. m., 579.

79 Az Európai Parlament és a Tanács 1215/2012/EU rendelete (2012. december 12.) a polgári és kereskedelmi ügyekben a joghatóságról, valamint a határozatok elismeréséröl és végrehajtásáról (HL L 351. 2012. 12. 20., 1-32.)

${ }^{80}$ HARSÁGI Viktória: A nem vitatott követelések végrehajtása az Európai Igazságügyi Térségben, Európai Jog, 5. évf. (2005) 6., 29. 
okiratra vonatkozó tanúsítványt - bírósági határozat vagy bírósági egyezség alapján - kérelemre, az első fokon eljárt bíróság állítja ki (Vht. 31/C §). Közokirat esetében a közokiratot kiállító hatóság székhelye szerint illetékes járásbíróság jár el. Külön szabályozás vonatkozik a közjegyzőre, aki az általa kiállított közokirat, általa hozott végzés vagy jóváhagyott egyezség alapján maga állíthatja ki a tanúsítványt vagy a kivonatot [Vht. § 31/C § (2) bek.].

2005 óta a magyar bíróságok kevés tapasztalatot szereztek a 805/2004/EK rendelet alkalmazásában. Statisztikai adatok szerint a határon átnyúló végrehajtási ügyek mindössze $10 \%$-ánál került sor közvetlen végrehajtásra. Ezek a körülmények is szerepet játszottak abban, hogy a Magyar Kormány 2009-ben - a Brüsszel I. rendelet felülvizsgálatáról szóló Zöld Könyvre ${ }^{81}$ adott válaszában - idő elöttinek minősítette az exequatur eljárás teljes körű eltörlését. A magyar álláspont szerint „a rendeletek ismerete és azok helyes alkalmazása még nem kielégítő mértékü". A másik ellenérv szerint az exequatur eljárás megszüntetése esetén „a tagállamok teljes mértékben a belső jog által szabályozott végrehajtási eljárásba fogják a szürőket beépíteni. Ez pedig azzal a nemkívánatos következménnyel járna, hogy a tagállami bíróságok határozatainak az eddigiekkel szemben nem egy egységes követelményrendszernek, hanem akár 27 egymástól eltérő szabályozásnak kellene megfelelnie, attól függően, hogy melyik tagállamban kérik annak végrehajtását" ${ }^{82}$

A Zöld Könyv megosztotta a tagállamokat az exequatur eljárás eltörlésének a kérdésében. ${ }^{83} \mathrm{Az}$ ellenvélemények azonban nem tartották vissza a Bizottságot attól, hogy 2010-ben egy radikális javaslattal álljon elö, amely a Brüsszel I. rendelet hatálya alá tartozó valamennyi bírósági határozat esetében - a becsületsértési ügyekben és a kollektív kártérítést érintő jogorvoslati ügyekben hozott határozatok kivételével - eltörölni kívánta az exequatur eljárást. Az alperesek jogvédelmét továbbra is azokkal a jogorvoslati eszközökkel kívánta biztosítani, „,amelyek kivételes körülmények között megakadályozhatják, hogy az egyik tagállamban hozott határozat hatályba lépjen egy másik tagállamban".

Az exequatur eltörlésére tett javaslat élénk visszhangot váltott ki ${ }^{84} \mathrm{~A}$ jogirodalom számos érvet hozott fel a végrehajthatóvá nyilvánítás megtartása mellett, amelyben a nemzeti szuverenitás megóvását, a tisztességes eljárás biztosítékát és az emberi jogok védelmét látta, továbbá kételkedett abban is, hogy a viszonylag egyszerủ eljárás eltörlése valóban hozzájárul-e a költségek csökkentéséhez, és egyéb problémák megoldásához. ${ }^{85}$ Oberhammer ugyan a végrehajthatóvá nyilvánítást az

$81 \operatorname{COM}(2009) 175$ végleges.

$82 \mathrm{http} / / /$ ec.europa.eu/justice/news/consulting_public/0002/contributions/ms_governments/hungary_hu.pdf (2014. 06. 21.).

83 ReChBeRger: Grenzenloses Vertrauen ... i. m., 1294-1295.

84 Vö. KRAmer: i. m., 202-230; Schack: The misguided abolition of exequatur... i. m., 1345-1369; Oberhammer: i. m., 193-207; Schlosser, Peter: The Abolition of Exequatur Proceedings - Including Public Policy Review. Praxis des Internationalen Privat und Verfahrensrecht, Vol. 30 (2010) Nr. 2, 101-104; Beaumont, PaulJohnston, Emma: Abolition of the Exequatur in Brussels I: Is a Public Policy Defence Necessary for the Protection of Human Rights? Praxis des Internationalen Privat und Verfahrensrecht, Vol. 30 (2010) No. 2, 105-110; CunibertI, Gilles-RuedA, Isabelle: Abolition of Exequatur. Adressing the Commission's Concerns. Rabels Zeitschrift für ausländisches und internationales Privatrecht, Vol. 73 (2011) Nr. 10, 286-317.

85 Kramer: i. m., 214-215. 
„idejétmúlt nacionalizmus maradványának” nevezte, amelyet a Bizottság feláldozott a kölcsönös bizalom oltárán, de nem tartotta meggyőzőnek azt az érvelést, hogy a közrendi záradékot a végrehajthatóvá nyilvánítás során csak kivételes esetekben alkalmazták. ${ }^{86}$ Rauscher szerint ez olyan, mintha az ejtőernyős azért mondana le a tartalékernyőröl, mert a föernyő többnyire kinyílik. ${ }^{87}$

A Bizottság érvei között fontos szerepet kapott a kölcsönös bizalom, amelynek megerősítését a Stockholmi Program is meghirdette. ${ }^{88} \mathrm{~A} 2010$. évi javaslathoz füzött indokolás szerint „,a tagállamok közötti igazságügyi együttműködés és az egymásba vetett bizalom immár megérett ahhoz, hogy továbbléphessünk a határozatok mozgásának egyszerübb, kevésbé költséges és automatikusabb rendszere felé, a tagállamok közötti meglévő alakiságok felszámolásával". ${ }^{89}$ De mi is az a kölcsönös bizalom? Az igazságügyi együttmüködés axiómája, amelynek a fogalmát Kramer szerint „sohasem határozták meg világosan és nem is elemezték az Európai Unió kontextusában". ${ }^{90}$ A Stockholmi Program, illetve a végrehajtásáról szóló cselekvési terv ${ }^{91}$ szerint a kölcsönös bizalom növelhető az eljárásjogi minimumszabályok harmonizálása, a különböző jogi tradíciók és módszerek jobb megismerése, a bírák és más szakemberek képzése, valamint a modern elektronikus kommunikációs eszközök fokozottabb kihasználása révén.

A 2012. december 12-én elfogadott normaszöveg a rendelet hatálya alá tartozó valamennyi bírósági határozat (bírósági egyezség és közokirat) tekintetében kimondta „a végrehajtás előtti végrehajthatóvá nyilvánítás eltörlését” (26. cikk), anélkül, hogy az eljárás lényeges elemeit számüzte volna a rendszerből. Az átdolgozott Brüsszel I. rendelet megtartotta a megtagadási okokat (45. cikk), köztük a sokat vitatott közrendi záradékot, valamint a háromszintủ bírósági eljárást is (48-50. cikk), de ezeket a szabályokat az elismerés, illetve a végrehajtás megtagadásáról szóló szakaszba ültette át. Egyetértünk Kaliczka azon megállapításával, miszerint „az új rendelet nem egyszerűen beemelte a régi Brüsszel I. rendelet szerinti eljárás kontradiktórius szakaszát, hanem gyakorlatilag egy jól működő rendszert zúzott szét [...], hiszen az eljárás kontradiktórius szakasza semmilyen valódi újítást nem hordoz, és semmilyen lényegi könnyítést nem kínál". ${ }^{22}$ Noha a végrehajthatóvá nyilvánítás mint eljárás, a Brüsszel I. rendeletben formálisan megszünt, a funkcionális azonosság miatt „forradalmi újitásról" mégsem beszélhetünk. ${ }^{93}$

86 Oberhammer: i. m., 201.

87 RAUSCHER, Thomas: Vollstreckung von Zivilentscheidungen aus Europa und Drittstaaten in Deutschland Ein Versuch der Systematisierung. International Journal of Procedural Law, Vol. 1 (2011) Nr. 2, 290.

88 A Stockholmi Program - a polgárokat szolgáló és védő, nyitott és biztonságos Európa (HL L 115., 2010. 5. 4., 13).

$89 \operatorname{COM}(2010)$ 748/4: 2.1.1. Az exequatur eltörlése.

90 KRAmer: i. m., 218.

$91 \operatorname{COM}(2010) 171$ végleges.

92 KaLICZKA: A védekezéshez való jog... i. m., 229.

93 KaLıCZKA Alexandra: Határon átnyúló végrehajtás - exequatur nélkül, Európai jog, 14. évf. (2014) 2., 15. 


\section{Zusammenfassung}

Am 10. Januar 2015 begann eine neue Zeitrechnung für das Zivilprozessrecht der Europäischen Union. Die Brüssel I. Verordnung (44/2001/EG) als wichtigste Rechtsquelle wurde mit einer Neufassung (1215/2012/EU) abgelöst. Die neue Verordnung schaffte die Vollstreckbarerklärung (Exequatur) als zwischen der Anerkennung ausländischer Entscheidungen und derer Vollstreckung keilendes Verfahren ab, was in der Rechtsliteratur als Paradigmenwechsel bewertet wird. Aus diesem Anlaß stellt der Verfasser eine Bilanz auf. Ihre Abhandlung befasst sich mit der rechtlichen Natur der Vollstreckbarerklärung, mit der Anwendung der Verfahrensregeln in dem ungarischen Rechtsverkehr und widmet ein Kapitel den Argumenten und Gegenargumenten in Bezug auf die Abschaffung der Vollstreckbarerklärung. 